\title{
Contributions of Muscle-Resident Progenitor Cells to Homeostasis and Disease
}

\author{
Devaveena Dey ${ }^{1} \cdot$ David J. Goldhamer ${ }^{2} \cdot$ Paul B. Yu ${ }^{1}$
}

Published online: 10 October 2015

(C) Springer International Publishing AG 2015

\begin{abstract}
Adult skeletal muscle maintains a homeostatic state with modest levels of cellular turnover, unlike the skin or blood. However, the muscle is highly sensitive to tissue injury, which unleashes a cascade of regenerative and inflammatory processes. Muscle regeneration involves crosstalk between numerous cytokine signaling axes, and the coordinated activity of multiple muscle-resident and circulating progenitor populations. Satellite cells, closely associated with myofibers, are established as the canonical muscle stem cell, with selfrenewal and myofiber-regenerating capacity. However, a heterogeneous group of mesenchymal progenitor cells residing within the muscle interstitium are also highly responsive to muscle injury and exhibit varying degrees of regenerative potential. These cells interact with satellite cells via direct and indirect mechanisms to regulate regeneration or repair. We describe the known phylogenetic and functional relationships of the multiple progenitor populations residing within skeletal muscle, their putative roles in the coordination of injury repair, and their possible contributions to health and disease.
\end{abstract}

Keywords Muscle stem cell · Satellite cell $\cdot$ Muscle interstitial cell $\cdot$ PIC $\cdot$ Fibro-adipogenic progenitor $\cdot$ Pericyte

This article is part of the Topical Collection on Molecular Biology of Adult Stem Cells

Paul B. Yu

pbyu@partners.org

1 Division of Cardiovascular Medicine, Department of Medicine, Brigham and Women's Hospital, 20 Shattuck Street, Thorn Biosciences 1203A, Boston, MA 02115-6119, USA

2 Department of Molecular and Cell Biology, University of Connecticut Stem Cell Institute, University of Connecticut, Storrs, CT 06269-3125, USA

\section{Introduction}

Recent work has demonstrated the presence and physiologic function of distinct stem cell populations within the solid tissues of adult organisms [1]. A relatively small population of tissue-resident "adult stem cells" possesses the ability to replenish the functional cells comprising adult tissue, while maintaining their own population by the phenomenon of self-renewal. Skeletal or striated muscle is a complex tissue predominantly comprised of myofibers, the functional unit of muscle. Each myofiber is a multinucleated giant syncytium, enclosed within the plasma membrane, "sarcolemma," and surrounded by an extracellular matrix, the basal lamina. Located in between the sarcolemma and basal lamina are the satellite cells [2], which have been defined as the canonical adult muscle stem cells, based on their potential for selfrenewal and ability to replenish damaged muscle fibers. Outside of the basal lamina, in the muscle interstitium resides a heterogeneous population of progenitor cells known collectively as "muscle interstitial cells" [3]. Both satellite and interstitial cells respond to muscle damage via distinct mechanisms and contribute to regenerative and repair processes. There is extensive crosstalk between the satellite and interstitial cell compartments, forming a complex, dynamic regenerative microenvironment in skeletal muscle (Fig. 1a).

\section{The Satellite Cell Compartment}

Satellite cells, considered the master stem cells of skeletal muscle regeneration, are the best characterized skeletal muscle-resident progenitor population. Named for their close juxtaposition with mature myofibers, satellite cells were first observed in electron microscopic studies of myofibers dissected from tibialis anterior muscles of the frog [4]. It was 
a
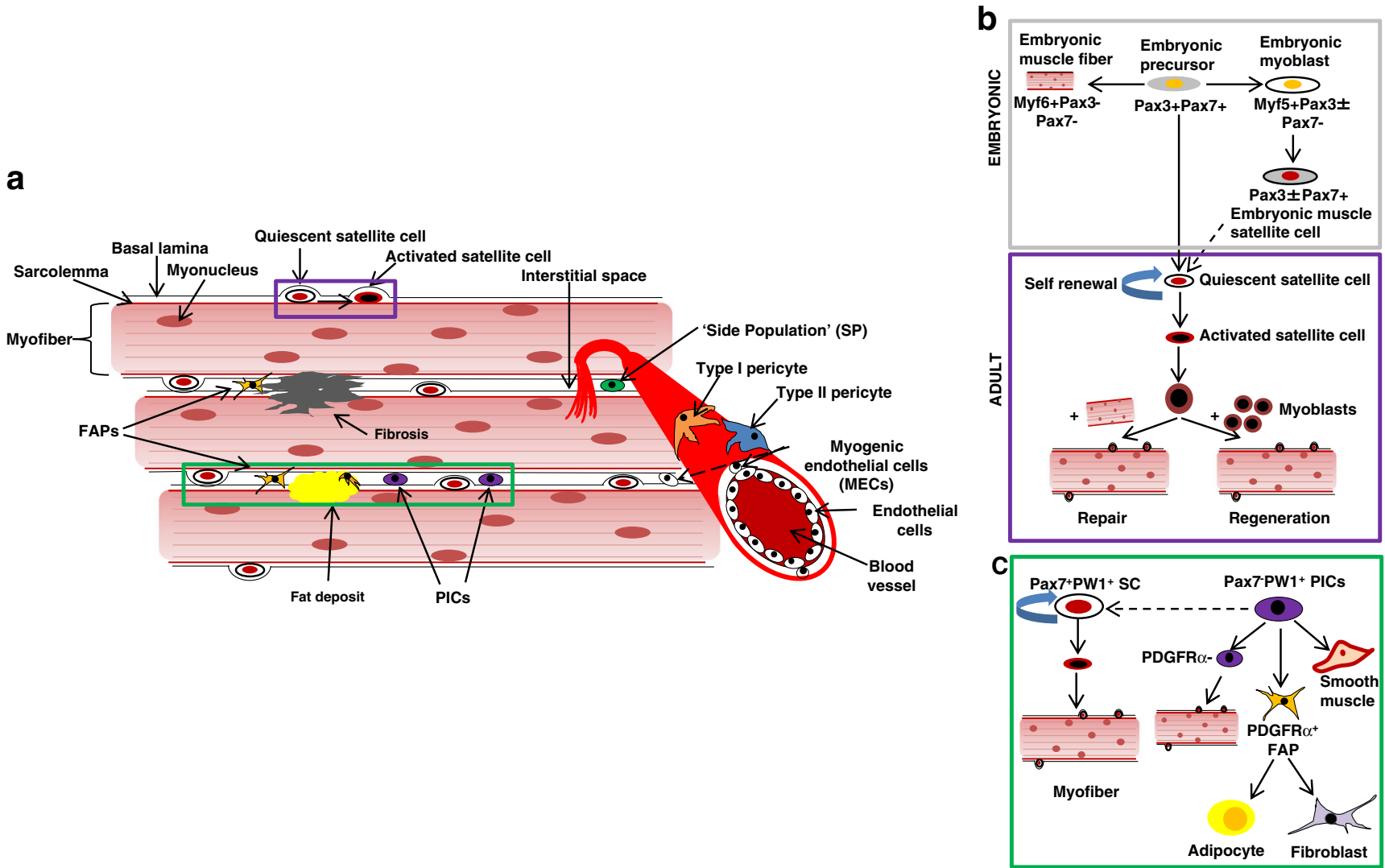

Fig. 1 Anatomical location of muscle progenitor cells. a Diagrammatic representation of muscle progenitor cells described thus far, in context of the myofiber, the structural and functional unit of skeletal muscle. FAPS fibro-adipogenic progenitors; PICs PW1+ interstitial cells. Inset shows b diagrammatic representation of the embryonic origin of satellite cells

subsequently observed that myofibers isolated from different anatomical locations exhibited different densities of satellite cells [5], as extensor digitorum longus or tibialis anterior muscles contain seven to nine satellite cells per myofiber, while soleus muscles contain $>20$ satellite cells per myofiber. Similar to adult stem cells found in other tissues, such as epidermal or neural stem cells, satellite cells remain mitotically quiescent in the steady state [6•]. Once activated by extrinsic signals, however, these cells undergo active proliferation and give rise to myoblasts, a pool of myogenic progenitors which can fuse to existing myofibers or form new muscle fibers to repair damaged muscle [7, 8]. During cell division, a subpopulation of activated satellite cells exit the cell cycle and return to quiescence to replenish the satellite cell pool [9], doing so by asymmetric cell division (Fig. 1b) [10]. Activation of satellite cells is typically mediated by exercise or any form of physical or chemical muscle trauma.

\section{Satellite Cell Markers}

The transcription factor Pax7 has been utilized as a canonical marker of satellite cells in humans and mice [11], defining an (top) and phenomenon of adult myogenesis (bottom), demonstrating the two hallmark properties of satellite cells: self-renewal and differentiation; and $\mathbf{c}$ the relationship of PICs to satellite cells and FAPs, in addition to their multilineage differentiation potential

anatomically and functionally restricted subset of myofiberassociated cells [12]. A number of surface and lineage markers that are relatively restricted to satellite cells within the context of muscle tissue have also been identified. SM/C-2.6, a monoclonal antibody developed by Fukada et al., binds to the cell surface of murine sublaminar $\operatorname{Pax} 7^{+}$cells, which also coexpress M-Cadherin [13]. This group and others have gone on to demonstrate that satellite cells in mice are highly enriched among a subfraction of total myofiber-associated cells lacking hematopoietic and endothelial lineage markers, as well as Sca-1 (CD45 $\left.{ }^{-} \mathrm{CD} 31^{-} \mathrm{Sca}^{-}\right)$[14••]. Despite the high level of enrichment of myogenic activity among Pax $7^{+}$lineages, it is acknowledged there is significant functional and phenotypic heterogeneity among this population [15]. A prospective approach to isolating highly myogenic fractions of this population yielded a highly homogeneous $\mathrm{CD} 45^{-} \mathrm{Sca}^{-} \mathrm{Mac}^{-} \mathrm{CXCR}^{+} \beta 1$-integrin ${ }^{+}$subpopulation of satellite cells capable of regenerating muscle from single cells in mice $[15,16]$. An analogous surface marker profile was recently described for human satellite cells, where the $\mathrm{CD}^{2} 5^{-} \mathrm{CD} 11 \mathrm{~b}^{-} \mathrm{GlyA}^{-} \mathrm{CD} 31^{-} \mathrm{CD} 34^{-}{ }^{-} \mathrm{TGA} 7^{\mathrm{hi}}$ surface phenotype was shown to mark $\operatorname{Pax} 7^{+}$fetal human myogenic cells 
[17•]. Adult human satellite cells could also be enriched using the same markers, but the frequency of these cells in adult muscle was $>5$-fold lower than in fetal tissues. Interestingly, the cell population enriched from human muscles using this marker profile was found to exhibit both myogenic and osteogenic potentials. While a similar bipotency has not been described for rodent satellite cells in the quiescent state, following burn injury these cells acquire an osteogenic profile, at least in vitro [18]. Similarly, enhanced expression of ITGA7 was shown to increase muscle regeneration and longevity in muscular dystrophic $\left(M d x^{-/-}\right)$mice [19], suggesting ITGA7 contributes to satellite cell functions required for maintaining skeletal muscle structure and function with age. In addition to identifying surface markers unique to satellite cells and their subpopulations, lineage-tracing techniques have been helpful for delineating the function of satellite cell subcompartments [5]. Using Myf5-Cre and Rosa26-YFP reporter alleles, Kuang et al. elegantly demonstrated that $\sim 10 \%$ of sublaminar Pax $7^{+}$ cells are Myf5 ${ }^{-}$, and these Pax $7^{+} \mathrm{Myf5}^{-}$subpopulations undergo asymmetric division to yield apical $\mathrm{Pax} 7^{+} \mathrm{Myf5}^{+}$committed myoblast progenitors and basal $\mathrm{Pax} 7^{+} \mathrm{Myf}^{-}$undifferentiated satellite cells, facilitating repair while replenishing the satellite cell reservoir [10]. Consistent with a theme found in satellite cells and muscle-resident myoprogenitor cells in general, significant changes occur in the composition and function of this reservoir with aging and activation following injury.

\section{Activation Versus Quiescence of Satellite Cells}

The cellular and molecular regulation of quiescence and activation in satellite cells has been a subject of intensive investigation. Whereas uninjured satellite cells do not divide, mechanical-, chemical-, or radiation-induced injury activates satellite cells to undergo proliferation. The cues for this activity are derived from the niche, as transplantation of single isolated myofibers and their associated satellite cells into irradiated muscle is sufficient to trigger the extensive proliferation of donor satellite cells, regeneration of new myofibers, and replenishment of the satellite cell pool [5]. A hierarchy of myogenic regulatory factors (MRFs) has been implicated in the process by which satellite cells transition to myoblasts to accomplish muscle regeneration. MyoD, long considered a master regulator of myogenic differentiation, is expressed in satellite cells as they become committed towards a myogenic fate, consistent with the role of MyoD in embryonic muscle development [20, 21••]. Similarly in embryonic development, there is functional redundancy of MyoD and Myf5, which together serve spatiotemporally distinct but overlapping functions as MRFs and markers of myogenic commitment [22]. Recently, it was found that MASTR, a member of the myocardin-related transcription factor (MRTF) family involved in serum response factor-mediated transcription in smooth muscle, is essential for the regulation of MyoD via a specific enhancer region, and precedes $\mathrm{MyoD}$ in the regulation of myogenic fate in satellite cells [23].

Pax7 itself appears to be necessary for the maintenance of the satellite cell compartment, its loss being associated with gradual attrition of the satellite cell compartment due to its anti-apoptotic function [24•]. Based on genetic ablation studies, Pax7 also appears to play an essential role for muscle regeneration following injury $[25 \bullet \bullet, 26 \bullet \cdot, 27 \bullet \bullet]$, while its role in mechanical load-induced hypertrophy is less clear. The Pax 7 promoter is tightly regulated by epigenetic modifications that are highly responsive to external stimuli from the satellite cell niche [28•] as well as injury [29]. Some of these epigenetic modifications were shown to be mediated by noncoding RNAs, in addition to the conventional histone modifiers [ $\left.30^{\bullet}\right]$. The transcription factor FOXO3 has been recently shown to promote quiescence in adult muscle satellite cells, via activation of the Notch signaling pathway, specifically NOTCH1 and NOTCH3 receptor expression [31].

\section{Extracellular Regulation of Satellite Cell Activation Versus Quiescence}

Growth factors and inflammatory cytokines released in the satellite cell niche play a critical role in governing satellite cell activation and quiescence, via differential regulation of myogenic versus proliferative genes. Myostatin (GDF8), a member of the TGF- $\beta$ superfamily, maintains satellite cell quiescence by upregulating p21 and inhibiting CDKs [32]. Quiescent satellite cells in uninjured muscle exhibit a $\mathrm{CD} 31^{-} \mathrm{CD} 45^{-} \mathrm{Sca}{ }^{-} \mathrm{VCAM}^{+}$surface phenotype in addition to expressing Pax7, whereas injury-activated satellite cells retain a similar cell surface marker profile but lose Scal in a portion of cells, while gaining MyoD [12, 14••]. There has been some controversy with regard to the expression of Sca1 among satellite cells, possibly due to its dynamic regulation in this compartment. STAT3 mediates the activation of MyoD expression downstream of IL-6 in the myogenic differentiation of satellite cells, whereas Pax7-specific deletion of STAT3 enhances satellite cell proliferation at the expense of diminished myogenic differentiation and myofiber repair activity, suggesting a critical function of STAT3 in regulating the balance between proliferation, differentiation, and replenishment of this compartment [31]. It was also shown that TNF- $\alpha$ activated p38 MAPK signaling results in chromatin remodeling of myogenic differentiation genes (Myogenin, Myosin heavy chain (MHC), Myosin creatine kinase (MCK)) and repression of Pax7 in activated satellite cells [33], also enhancing myofiber regeneration. Another TNF- $\alpha$-like proinflammatory cytokine, TWEAK, was shown to suppress satellite cell self-renewal by activating NF- $\mathrm{KB}$ and inhibiting Notch signaling [34•]. Conversely, inhibition of the TNF- $\alpha$ receptor-associated factor 6 (TRAF6) improved satellite cell activation via 
upregulating Notch signaling and inhibiting NF-kB [35•], confirming the reciprocal relationship between Notch signaling and NF-KB pathway in satellite cell activation. Secretion of chemokines in the local microenvironment can also dictate satellite cell function, as a recent study demonstrated a regulatory function of the monocyte chemoattractant protein (MCP-1/CCL2) secreted by $\mathrm{CD} 8^{+} \mathrm{T}$ cells in injured muscle, acting to promote myoblast proliferation by recruiting the infiltration of $\mathrm{Gr} 1^{\text {high }}$ macrophages [36•]. In addition to inflammatory cytokines, presence of growth factors such as HGF and LIF was also shown to upregulate MRFs including MyoD and Myogenin, while repressing myostatin in activated satellite cells, in part by activation of the Akt/mTOR/p70S6K protein synthetic pathway [37].

\section{Intracellular Regulation of Satellite Cell Activation Versus Quiescence}

The transition from a quiescent to an activated state also entails widespread metabolic changes within satellite cells $[6 \bullet$, 38•]. A recent study demonstrated the necessity of autophagy for meeting the bioenergetic demands of satellite cells during the transition from quiescence to activation [39•]. Shan et al. reported that the serine-threonine kinase Lkb1 inhibits satellite cell proliferation via the AMPK/mTOR pathway, yet facilitates differentiation through phosphorylation of GSK-3 $\beta$ to modulate Wnt signaling [40 ${ }^{\bullet}$. A study by Rodgers et al. recently showed that mTORC1 activity, in addition to cMet/HGF signaling, is necessary and sufficient for the transition from quiescence or $\mathrm{G}_{0}$ to a reversible transition or " $G_{\text {alert }}$ " state that is primed for rapid entry into the cell cycle under stress or injury [41•]. The authors demonstrated that this was a universal mechanism of activation in multiple populations of adult, tissue-resident quiescent stem cells.

\section{The Aging Satellite Cell}

A body of work has now shown several critical aging-related changes affecting the satellite cell population, including a reduction in their number; impaired response to growth factors and cytokines; impairment of intracellular signaling pathways regulating growth (e.g., Notch); changes in mitochondrial number, content, or mitophagy; increased levels of extraand intracellular reactive oxygen species (ROS); and increased DNA damage [42]. An earlier study implicated increased Wnt signaling in aging mice as the underlying cause of increased fibrosis, and decreased muscle regeneration [43]. Myostatin, in addition to maintaining satellite cell quiescence, appears to contribute to age-related muscle degeneration by generating ROS in muscle cells via the activation of proteosomal-mediated catabolism of intracellular proteins [44]. Indeed, haploinsufficiency of myostatin enhances longevity of mice and protects against age-related decline in muscle function [45]. Following deletion of myostatin, aging muscles exhibit enhanced activity of antioxidant enzymes, reduced NF- $\mathrm{KB}$ levels, and efficient scavenging of ROS, resulting in the normalization of age-related muscle damage as compared to wild type [44]. Study of geriatric satellite cells recently revealed that the mechanistic basis of satellite cell aging is the irreversible conversion of the quiescent state to a senescent state, caused by loss of repression of p16INK4a [46••]. In this context, muscle injury or stress fails to activate these cells, resulting in sarcopenia.

\section{Muscle Interstitial Cells: Myogenic Niche or Alternative Progenitor Cells?}

The heterogeneous population of cells located within the muscle interstitium includes a number of important tissue-resident progenitor cell candidates located outside the myofiber basement membrane $[47 \bullet \bullet, 48 \bullet \bullet$ ] (Fig. 1a). These cells, also called myofiber-associated cells based on their anatomic location, have numerous subpopulations with apparently diverse phylogenetic origins, surface phenotypes, and capacities to serve as myogenic or mesenchymal progenitor cells.

\section{Adipogenic and Fibro-adipogenic Progenitors}

Uezumi and colleagues recently described a muscle interstitial cell population notable for the expression of high levels of PDGFR $\alpha$ and the lack of lineage markers CD31 and CD45, which efficiently gave rise to adipocytes in vitro and are expanded in injured muscles undergoing fatty degeneration $[47 \cdot 0]$. This population was more abundant in young, healthy skeletal muscle, and appeared to be the exclusive cell type in this niche committed to adipogenic differentiation. The adipogenic differentiation of this lineage was dependent on the type of muscle injury and microenvironment, as these progenitors would proliferate and undergo adipogenic differentiation in a glycerol injury model, but not following cardiotoxin injury, consistent with the efficient induction of fatty degeneration by glycerol injury. Interestingly, satellite cells inhibited the adipogenic differentiation of these interstitial progenitors, and did so in a manner requiring direct cellcell contact with adipogenic progenitors, whereas soluble factors elaborated by satellite cells were insufficient. Joe and colleagues subsequently found that this same PDGFR $\alpha^{+}$interstitial population had the capacity to differentiate into either fibroblasts or adipocytes, calling them fibro-adipogenic progenitor (FAP) cells [48••], and could be further distinguished by their $\mathrm{CD} 31^{-} \mathrm{CD} 45^{-} \mathrm{Scal}^{+} \alpha 7$-integrin ${ }^{-}$surface marker phenotype. Subcutaneous transplantation, or intramuscular transplantation of FAPs into muscles, was observed to yield adipocytes in muscles undergoing fatty infiltration but not in healthy muscles. Uezumi and colleagues similarly showed 
that the $\mathrm{CD} 31^{-} \mathrm{CD} 45^{-} \mathrm{PDGFR}^{+}$interstitial FAP population undergoes both fibro- and adipogenesis in vitro, as well as in cardiotoxin-damaged and myopathic muscles in vivo [49•]. FAPs are quiescent in resting muscles and do not engraft healthy muscles, but proliferate rapidly following tissue damage, with extensive adipocyte differentiation, and with their numbers returning to basal levels within 5-7 days after injury. In contrast to the exclusively adipogenic progenitors, FAPs were seen to promote myofiber differentiation and muscle regeneration, in a manner which appeared to depend on both cell-cell contact and secreted factors such as IL-6. PDGFR $\alpha^{+}$ cells are highly responsive to TGF- $\beta$ and PDGFR $\alpha$ signaling, particularly in the context of injury, secreting in response high levels of pro-fibrotic and extracellular matrix (ECM) remodeling genes including type I and type III collagen, connective tissue growth factor (CTGF), and tissue inhibitor of metalloproteinase (TIMP1) [49•].

FAPs appear to regulate satellite cell function in an agedependent manner by modifying the cytokine microenvironment. Using HDAC inhibition as a trigger for muscle regeneration, Mozzetta et al. demonstrated that FAPs from young $M d x^{-/-}$mice promote myotube formation in satellite cells, whereas the same treatment fails to induce muscle regeneration in older $M d x^{-1-}$ mice due to repression of myotube formation by aged FAPs [50]. Transplantation of young FAPs in old $M d x^{-/}$mice restored the regenerative effects of HDAC inhibition. The myo-regenerative effect of HDAC inhibition in young mice was found to require the secretion of follistatin, an Activin A antagonist, and was consistent with the regulation of satellite cell function by the response of interstitial cells to injury and their ability to modify the local microenvironment [50].

\section{Pericytes and Mesangioblasts}

Myofibers are invested with capillary networks that supply blood to the tissue (Fig. 1a). Each capillary is lined by endothelial cells on the luminal surface of the vessel wall and is wrapped on the abluminal surface, next to the basal lamina, by mural cells or pericytes [51] and adventitial cells [52•]. Pericytes exist throughout all organ beds, with important functions in tissues including brain [53], heart, lung [54], and skeletal muscles [55, 56], and are suggested to serve as organ-specific mesenchymal cell reservoirs for tissue repair [57]. While the lineage relationship of pericyte populations residing in different tissues remains incompletely resolved, the cells which share this anatomic specialization in diverse tissues have in common several surface markers including NG2 and PDGFR $\beta[54,56,58]$.

Mural cells or pericytes are thought to be ontogenically related to "mesangioblasts," a class of vessel-associated fetal stem cell capable of giving rise to all mesodermal lineages [59]. In fact, one study demonstrated that intra-arterial delivery of mesangioblasts isolated from dorsal aortae of fetal or neonatal mice into mice with dystrophic or injured muscles resulted in the homing of some of these cells beneath the basal lamina, expression of the satellite cell marker, M-Cadherin, and integration of some into muscle capillaries close to degenerating and regenerating muscle areas. Homing of these cells to injured muscles was enhanced in the presence of cytokines such as TNF- $\alpha$ and SDF1, with significant restoration of damaged muscles in multiple muscular dystrophy models [60]. Mesangioblast cells do not appear to participate in myogenesis in steady-state muscle but are extremely sensitive to inflammatory triggers.

Adult pericytes similarly exhibit impressive myoregenerative capacity. The capacity of muscle-resident pericytes to undergo myogenic differentiation independently of satellite cells was demonstrated in 2007 by Dellavalle et al. using muscle biopsy samples from human muscular dystrophy patients and control individuals [55]. This myogenic capacity distinguished pericytes from the classical bone marrowderived mesenchymal stem cells (MSCs). Pericytes express multiple cytoskeletal and ECM proteins at high levels, such as Desmin, Vimentin, and smooth muscle actin, in addition to NG2 and PDGFR $\beta$. Despite their shared myogenic potential, pericytes contribute to myogenesis in a very distinct manner from satellite cells. Pericytes are typically found under the basal lamina of blood vessels associated with skeletal muscle, removed from the compartment of satellite cells beneath the myofiber basal laminae. During postnatal development, pericytes fuse with developing myofibers, contributing to the satellite cell pool, and more so following injury [61•]. Pericytes proliferate extensively in culture and, in contrast to satellite cells, do not express M-Cadherin or myogenic transcription factors such as MyoD, Myogenin, or Myf 5 during proliferation - these markers are only found in pericytederived myofibers. Pericytes express high levels of alkaline phosphatase (ALP) and lack CD56, while satellite cells are $\mathrm{ALP}^{-} \mathrm{CD} 56^{+}$. In addition, pericytes can home into the muscles and regenerate myofibers after systemic delivery through the femoral artery [55], while satellite cells fail to cross vessel walls and integrate in muscle, highlighting the clinical potential of pericytes in muscle regeneration therapy.

Within skeletal muscle, functional subsets of pericytes have been described. So-called type I pericytes of a Nestin ${ }^{-} \mathrm{NG}^{+}$ lineage harbored important functional as well as phenotypic differences from Nestin ${ }^{+} \mathrm{NG}^{+}$type II pericytes. While both types of pericytes express PDGFR $\beta$ and CD146, only type I pericytes express PDGFR $\alpha$ [56]. These heterogeneous pericyte populations in skeletal muscle appear to have distinct fate potential. Nestin ${ }^{+} \mathrm{NG} 2^{+} \mathrm{CD} 146^{+}$type II pericytes express high levels of the early neural progenitor marker, Tuj $1[62$, 63], and can differentiate into functional mature neural cells, unlike the Nestin $\mathrm{NG}^{+}$type I pericytes. In contrast to most previously described pericyte populations, the Nestin ${ }^{-}$type I pericytes lacked $\alpha$-smooth muscle actin expression [58]. 
The same group demonstrated that the Nestin $\mathrm{NG}_{2}^{+} \mathrm{CD} 146^{+} \mathrm{PDGFR} \alpha^{+}$type I pericytes could give rise to fat cells when injected in injured muscles, or give rise to fibrous tissue in aged skeletal muscle [64•], whereas type II pericytes isolated from young muscle participated in muscle regeneration following injury [56]. Interestingly, type II pericytes isolated from aged animals failed to participate in myofiber repair following injury, while type I pericytes contributed to enhanced fibrous tissue deposition within the interstitial space in aged muscle, consistent with age-dependent changes in interstitial cell myo-regenerative and tissue remodeling function similar to that observed with FAPs. In all studies, type I pericytes did not differentiate into myofibers [56, 58]. Given the fibro-adipogenic potential of the type I pericytes, it is interesting to speculate if these cells share lineage with some of the FAPs described earlier.

The molecular mechanisms underlying transition of pericytes from quiescence to a muscle-regenerating or fibroadipogenic phase are unknown. Through studies in other tissues, it appears that soluble factors secreted by pericytes, or their neighboring vascular smooth muscle cells (VSMCs) and endothelial cells (ECs), might play a role in their autocrine and paracrine activation in the regenerative process $[65,66]$. For example, thrombospondin and PDGF secreted by VSMCs appear to serve as promigratory and pro-proliferative signals for pericytes [67]. A recent study revealed a role of the soluble factor, Activin A, secreted by ECs, in directing the differentiation of neighboring adipose stromal cells (ASCs) to mural cells, the precursors of pericytes and vascular smooth muscle cells [68]. Whether pericytes from regenerating muscles secrete follistatin and promote muscle regeneration, as shown in the case of FAPs, is not known. Finally, as it holds for all other muscle interstitial cells, it would be interesting to investigate whether pericytes are supportive of or necessary for muscle regeneration, by ablating their population in vivo and studying myogenesis.

\section{The Side Population}

The side population (SP) is a functionally defined set of cells identified in diverse tissues that exhibit considerable plasticity and stem-like properties. The side population approach was originally used to enrich hematopoietic stem cells [69] and, in contrast to surface antigen-based phenotypic sorting strategies, relies on the efficient ability of many stem or progenitor cell populations to export drug-like molecules. In this case, SP cells exclude the fluorescent dye Hoechst 33342 via the activity of ATP Binding Cassette $(\mathrm{ABC})$ transporter proteins in the cell membrane. SP cells appear as a low-fluorescence retaining population that is readily distinguished by flow cytometry from the majority of cells that avidly retain dye within the main population (MP). Addition of an $\mathrm{ABC}$ transporter inhibitor, verapamil, abolishes the detection of SP by flow cytometry.
Using this technique, Gussoni et al. first reported the existence of Hoechst 33342 excluding SP interstitial cells within skeletal muscle, which were shown to have a broadly lineage negative, predominantly $\mathrm{CD} 45^{-} \mathrm{ckit}^{-} \mathrm{Sca} 1^{+}$surface phenotype [70]. Both muscle- and bone marrow (BM)-derived SP from wild-type C57BL/6 mice could successfully engraft into $M d x^{-/-}$mice, fuse with existing myofibers, and form new myofibers, normalizing dystrophin expression in these fibers. Further characterization of muscle-derived SP by Asakura et al. revealed that SP and satellite cells are distinct populations and that inductive signals from myocytes were necessary for myogenic differentiation of SP [71]. While muscle-derived SP expresses Scal and gives rise to hematopoietic colonies, satellite cells were Sca1 ${ }^{-}$and could not form hematopoietic colonies. SP were localized outside the basal lamina, in proximity to blood vessels. Muscle SP appeared to have both a hematopoietic $\left(\mathrm{CD} 45^{+}\right)$and non-hematopoietic $\left(\mathrm{CD} 45^{\circ}\right)$ component. Subsequently, it was demonstrated that muscle SP were derived from, and were in dynamic equilibrium with, bone marrow SP cells but had important functional differences from the BM-derived population of non-SP muscle interstitial cells [72]. For example, muscle-derived SP injected in injured muscles, in addition to undergoing myogenic differentiation, also engrafted onto the endothelium during vascular regeneration, and thus, at least a subset of muscle-resident SP appeared to function as vascular progenitors.

A recent study on SP cells isolated from WT mice demonstrated that these cells undergo efficient differentiation into satellite cells, and form myotubes [73•], independent of myoinductive signals from myocytes. These SP cells were Pax $7^{+}$, suggesting a lineage relationship to satellite cells; however, their surface marker profile was $\mathrm{CD} 45^{-} \mathrm{CD} 31^{-} \mathrm{Sca} 1^{+} \mathrm{PDGFR} \alpha^{+}$, in contrast to the typically $\mathrm{Scal}^{-}$and PDGFR $\alpha^{-}$phenotype of satellite cells. Interestingly, the SP cells expanded in dystrophic and cardiotoxin-injured muscle to give rise to FAPs, resulting in the formation of fibrotic and fatty lesions. Hence, while SP cells appear to replenish satellite cells in steady-state muscles, they can take on a fibro-adipogenic fate in injured muscles.

\section{Hematopoietic, Circulating, and Endothelium-Derived Myogenic Progenitors}

The contribution of the bone marrow to the replenishment of SP and other muscle-resident progenitor populations has suggested the bone marrow might serve directly as a source of myogenic progenitors $[72,74]$. Circulating $\mathrm{CD} 133^{+}$cells derived from the bone marrow can engraft diseased muscles to restore dystrophin expression, and exhibit increased adherence in response to the expression of VCAM1 in the vasculature of diseased muscles [75]. An earlier report had described in postnatal rat muscles the presence of a $\mathrm{CD} 34^{+} \mathrm{MyoD}^{-}$, a possibly hematopoietic stem cell-related subpopulation of interstitial cells that underwent extensive proliferation during 
early postnatal muscle growth, contributing to the formation of new myofibers [76]. It is currently not known if these cells have a relationship to the hematopoietic subsets of SP cells.

Each layer of the vascular wall (intima, media, and adventitia) appears to be a potential source of myogenic progenitors, including "myogenic endothelial cells" (MECs, found in intima of human capillaries), mesoangioblasts and pericytes (associated with the media), and adventitial cells [77]. MECs, which are present at very low frequencies in adult human skeletal muscles $(<0.5 \%)$, co-express myogenic (CD56) and endothelial (CD144) markers. CD56 ${ }^{+} \mathrm{CD} 144^{+} \mathrm{CD} 34^{+} \mathrm{CD} 45^{-}$ MECs proliferated over long term, had enhanced survival in oxidative stress, and could be induced to differentiate into osteo-, chondro-, adipo-, and myocytes in vitro [78]. Huang and colleagues found that myo-endothelial cells exhibited myogenic potential in vitro, but did not contribute appreciably to muscle development or muscle regeneration in vivo [79]. Rather, they found that myo-endothelial cells exerted an important intramuscular anti-adipogenic role in vivo which required intact type Ia bone morphogenetic protein (BMP) receptor signaling, While MECs and pericytes have been shown to actively participate in myogenesis, the role of adventitial cells has so far been demonstrated only in cardiomyocyte repair $[52 \bullet, 77]$.

\section{$\mathbf{P W}^{+} / \mathbf{P a x} 7^{-}$Interstitial Cells}

PW1 is a large zinc finger protein shown to be involved in $\mathrm{p} 53$ and TNF-NF-KB cellular stress responses [80, 81]. In $\triangle \mathrm{PW} 1$ mutant mice, fetal muscle development is intact, while postnatally muscles are severely atrophic, associated with a significant reduction in quiescent muscle satellite cells. As expected, these mice showed resistance to $\mathrm{p} 53$ - and $\mathrm{TNF}-$ mediated stress pathways [82]. These studies implicate PW1 as an important regulator of adult muscle homeostasis as well as a postnatal muscle stress sensor.

Subsequent studies demonstrated the expression of PW1 in satellite cells, as well as in a Pax $7^{-}, \mathrm{PW}^{+}$interstitial cell (PIC) population [83] (Fig. 1b). These two populations had distinct origins, with satellite cells but not PICs being derived from $\mathrm{Pax} 3^{+}$precursors. PICs were highly enriched for a Sca ${ }^{+} \mathrm{CD} 34^{+}$surface phenotype. Clonal analyses showed that a single PIC could give rise to both smooth and skeletal muscle [83], whereas PICs from $\mathrm{Pax} 7^{-/-}$mice could only give rise to smooth muscle. Moreover, while PICs were $\mathrm{Pax}^{-} \mathrm{MyoD}^{-}$in non-injured muscle, they would readily adopt a $\mathrm{Pax} 7^{+} \mathrm{MyoD}^{+}$phenotype with myogenic differentiation in vitro, a process that was amplified further in the setting of muscle injury. Despite the distinct origins of PICs and satellite cells, PICs could generate satellite cells as well as PICs. Thus, while PICs lacked Pax7 in the quiescent state, these data demonstrate that $\operatorname{Pax} 7$ is essential for myogenic specification of PICs. Interestingly, an inverse correlation was found between the number of PICs and satellite cells during early postnatal muscle development, suggesting a reciprocal relationship in the homeostatic regulation of these two progenitor pools.

In addition to their potential to differentiate into skeletal and smooth muscle cells, a recent study demonstrated that a PDGFR $\alpha^{+}$subpopulation of PICs exhibited high adipogenic potential, and in fact overlapped with interstitial adipogenic or fibro-adipogenic progenitors also expressing PDGFR $\alpha$ [84••]. In contrast, the myogenic subpopulations of PICs lacked PDGFR $\alpha$. PW1 consistently marks adult stem cells in multiple tissues, ranging from brain, skin, bone, skeletal muscle, and testis [85•], suggesting a central role of PW1-mediated stress response pathways in the activity of diverse tissueresident progenitor cells. This is not surprising, given the dependence of adult stem cell function on extrinsic and intrinsic microenvironments. Silencing PW1 inhibited the myogenic potential of vessel-derived mesangioblasts in vitro through MyoD degradation, and abrogated their migratory ability from vessels into damaged muscles in vivo via disruption of a junctional adhesion molecule [86•].

A possible unique and protective function of the PIC compartment has been observed in certain muscle tissues. Extraocular muscles (EOM) are not observed to undergo fibrosis or fat deposition even in late stages of disease in Duchenne's muscular dystrophy, in contrast to other skeletal muscles including the tibialis anterior [87]. Analysis of the EOM progenitor cell niche in $M d x^{-/-}$mice revealed that satellite cell density per myofiber was consistent between EOM and tibialis muscle, whereas the number of PICs was significantly

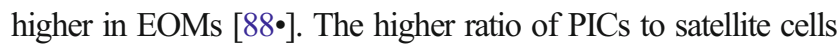
remained constant in the EOM irrespective of age, whereas with age there were progressive declines in the PIC to satellite cell ratio in the tibialis. Consistent with these observations, tibialis muscles from adult $M \mathrm{dx}^{-/-}$mice exhibit the effects of extensive degeneration and regeneration cycles, whereas the EOM stem cell niche resembled steady-state healthy wild-type muscle, suggesting that the enhanced number of PICs in the EOM niche may create a pro-myogenic environment. The increased secretion of growth factors like follistatin and IGF by PICs was proposed as one of the molecular mechanisms by which these cells might promote EOM myogenesis.

PICs are a heterogeneous and multipotent interstitial muscle population, with subpopulations exhibiting myogenic potential, fibro-adipogenic potential, as well as the capacity to regenerate the satellite cell pool. PICs may represent a primordial skeletal muscle-resident mesenchymal progenitor population that acquires a skeletal musclespecific myogenic potential in postnatal muscles, while retaining fibro-adipogenic and smooth muscle potential within subpopulations. 


\section{Misplaced Regeneration: Intramuscular Heterotopic Ossification}

While fibrosis and fatty degeneration are the most common response to injury or senescence in muscle, under some circumstances the formation of other mesodermal structures including cartilage and bone may be promoted. Heterotopic ossification (HO) as such describes the formation of ectopic bone in soft tissues, occurring commonly as a complication of tissue trauma including bone fractures, burn injuries, blast injuries, and joint replacement surgeries [89], which is a frequent cause of morbidity in these instances due to significant pain and immobility.
$\mathrm{HO}$ can also be triggered in the setting of inflammation, with entheseal ossification affecting the axial skeleton in ankylosing spondylitis and other spondyloarthropathies [90, 91]. HO can occur as part of a congenital syndrome called fibrodysplasia ossificans progressiva (FOP), caused by gain-of-function mutations in ACVR1 encoding the BMP type I receptor ALK2 [92], in which progressive replacement of skeletal muscle, cartilage, tendons, ligaments, and fascia with endochondral bone occurs postnatally, frequently triggered by antecedent injury or inflammation. The HO in these various syndromes, including FOP, appears to spare EOM, cardiac, vascular smooth muscle, and diaphragmatic muscle tissues. The anatomic distribution of

Table 1 Summary of the differentiated and undifferentiated cell types described in the skeletal muscle: location, function, and markers utilized to characterize and purify the cells

\begin{tabular}{|c|c|c|c|c|c|}
\hline $\begin{array}{l}\text { Cell } \\
\text { type }\end{array}$ & Name & Location & Function & Markers & Reference \\
\hline$\because \because$ & Myofiber & $\begin{array}{l}\text { Structural unit } \\
\text { of skeletal } \\
\text { muscle }\end{array}$ & $\begin{array}{l}\text { Functional unit of } \\
\text { skeletal muscle }\end{array}$ & $\begin{array}{l}\text { Myf6+, Desmin, } \\
\text { Myogenin }\end{array}$ & {$[17 \cdot, 99]$} \\
\hline & Myoblast & Sublaminar & $\begin{array}{l}\text { Committed myogenic } \\
\text { precursor }\end{array}$ & Myf5+Pax3 \pm Pax7- & [100] \\
\hline & $\begin{array}{l}\text { Activated } \\
\text { satellite cell }\end{array}$ & Sublaminar & $\begin{array}{l}\text { Short term myofiber } \\
\text { repair and regeneration }\end{array}$ & 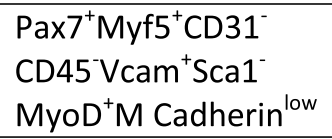 & {$[10,14 \cdot ., 101]$} \\
\hline 0 & $\begin{array}{l}\text { Quiescent } \\
\text { satellite cell }\end{array}$ & Sublaminar & $\begin{array}{l}\text { Long term myofiber } \\
\text { regeneration; self- } \\
\text { renewing population }\end{array}$ & $\begin{array}{l}\text { Pax7 }^{+} \text {Myf5 }^{-} \mathrm{CD}^{+} 1^{-} \\
\text {CD45 Vcam }^{+} \text {Sca1 } \\
\text { MyoD }^{-} \text {M Cadherin }\end{array}$ & {$[10,14 \cdot \cdot, 101]$} \\
\hline & $\begin{array}{l}\text { Fibroadipogenic } \\
\text { Progenitors } \\
\text { (FAPs) }\end{array}$ & $\begin{array}{l}\text { Perilaminar } \\
\text { (muscle } \\
\text { interstitium) }\end{array}$ & $\begin{array}{l}\text { Fibrosis and adipogenic } \\
\text { differentiation mediated } \\
\text { muscle repair }\end{array}$ & $\mathrm{CD}^{-} 1^{-} \mathrm{CD}^{-} 5^{-} \mathrm{PDGFR}^{+}$ & {$[47 .]$.} \\
\hline is & $\begin{array}{l}\text { Type I } \\
\text { pericytes }\end{array}$ & $\begin{array}{l}\text { Perivascular } \\
\text { (media) }\end{array}$ & $\begin{array}{l}\text { Adipogenic } \\
\text { differentiation in injured } \\
\text { muscle; fibrogenic } \\
\text { differentiation in aged } \\
\text { muscle }\end{array}$ & $\begin{array}{l}\text { Nestin } \\
\text { NG2 }^{+} \text {PDGFR } \beta^{+} \text {CD146 } \\
\text { PDGFRa }^{+}\end{array}$ & {$[63,102]$} \\
\hline & $\begin{array}{l}\text { Type II } \\
\text { pericytes }\end{array}$ & $\begin{array}{l}\text { Perivascular } \\
\text { (media) }\end{array}$ & Myogenic differentiation & $\begin{array}{l}\text { Nestin }^{+} \text {NG2 }^{+}{ }^{\text {PDGFR }}{ }^{+} \\
\text {CD146 }\end{array}$ & [63] \\
\hline e & $\begin{array}{l}\text { Side } \\
\text { population } \\
\text { (SP) }\end{array}$ & $\begin{array}{l}\text { Perilaminar } \\
\text { (muscle } \\
\text { interstitium) }\end{array}$ & $\begin{array}{l}\text { Myogenic differentiation } \\
\text { in steady state muscle; } \\
\text { Fibro-adipogenic } \\
\text { differentiation in injured } \\
\text { muscle }\end{array}$ & $\begin{array}{l}\mathrm{ABCG}^{+} \mathrm{CD} 31^{-} \mathrm{CD} 45^{-} \\
\mathrm{Sca1}^{+}\end{array}$ & {$[70,71]$} \\
\hline$\infty$ & $\begin{array}{l}\text { Myogenic } \\
\text { endothelial } \\
\text { cells }\end{array}$ & $\begin{array}{l}\text { Vascular } \\
\text { endothelium } \\
\text { (intima) }\end{array}$ & $\begin{array}{l}\text { Myogenic differentiation } \\
\text { in injured muscle }\end{array}$ & $\begin{array}{l}\mathrm{CD}^{+} 6^{+} \mathrm{CD} 144^{+} \mathrm{CD} 34^{+} \mathrm{C} \\
\text { D45 }\end{array}$ & [78] \\
\hline 0 & $\begin{array}{l}\text { PW1+Pax7- } \\
\text { Interstitial } \\
\text { cells (PICs) }\end{array}$ & $\begin{array}{l}\text { Perilaminar } \\
\text { (muscle } \\
\text { interstitium) }\end{array}$ & $\begin{array}{l}\text { Postnatal muscle stress } \\
\text { sensor; Skeletal and } \\
\text { smooth muscle } \\
\text { myogenesis }\end{array}$ & $\begin{array}{l}\text { Pax7 }^{-M_{1}{ }^{-}} \\
\text {Sca1 }^{+} \text {CD34 }\end{array}$ & [83] \\
\hline
\end{tabular}


these $\mathrm{HO}$ syndromes and their associated triggers may yield important clues as to the identity of the progenitors responsible for forming pathologic bone, providing strategies for the clinical management of $\mathrm{HO}$, or conversely, identifying novel reservoirs of bone progenitors for tissue engineering applications.

Various muscle-resident populations have previously been implicated in the development of HO. Satellite cells have been raised as a potential contributor to HO [93], based circumstantially on the increase in satellite cell frequency following burn injury [18], as well as the widely observed in vitro osteogenic potential of these cells $[17 \cdot, 94]$. However, no direct evidence of a contribution has been demonstrated to date. Similarly, an ex vivo study of cells isolated from healthy human skeletal muscle revealed pericytes to harbor the most potential for in vitro osteogenic differentiation [95]. More recently, enhanced frequencies of PDGFR $\alpha^{+}$interstitial cells have been observed in biopsied human muscle tissues directly adjoining HO lesions associated with trauma [96]. In a BMP-injection-induced model of HO, Tie2 lineage-marked cells were found to contribute to the osteocytes and chondrocytes of heterotopic bone, suggesting a possible vascular endothelial contribution to HO [97•]. A subsequent study refined this result by combining Tie2 lineage tracing with the analysis of other surface markers, showing that $\mathrm{Lin}^{-} \mathrm{Tie}^{+} \mathrm{CD} 31^{-}{ }^{-} \mathrm{PDGFR} \alpha^{+}, \mathrm{NG}^{-}{ }^{-}$interstitial cells contribute osteogenic and chondrogenic progenitors to HO lesions [98]. These data as a whole appear to implicate interstitial FAP-like cells as the primary reservoir of HO disease; however, more study must be done to determine how these cells might work in concert with other resident and bone marrowderived populations to mediate this disease. The phenomenon of HO highlights the multipotentiality of these various muscle-resident stem cell populations and demonstrates that these muscle-resident lineages represent bona fide mesenchymal progenitors that can contribute to multiple types of pathophysiology.

\section{Conclusions}

These studies demonstrate the importance of the muscle environment (associated with distinct injury stimuli) in regulating the dynamic interactions among various muscle-resident progenitors. The sublaminar satellite cell compartment represents a definitive self-renewing myogenic stem cell whose number, function, and phenotype appear to be closely co-regulated with several species of peri-laminar muscle interstitial cells. These interstitial populations include the PICs (Table 1), as well as other populations with overlapping surface and functional phenotypes including type I pericytes, FAPs, as well as a subpopulation of SP cells. The functional coupling of satellite cells with interstitial populations is evident in the sensitivity of the interstitial cells to muscle injury, leading to their joint activation, or in aging and myopathies, where their number, function, and sensitivity to injury-mediated signals are simultaneously compromised. The three principal fates imparted by these progenitor populations include myogenesis as part of skeletal muscle homeostasis and repair, or fibrosis and adipogenesis during muscle degeneration and senescence. It presently remains unclear whether the various subpopulations of muscle-resident progenitors are functional segregated or overlapping in these functions. For example, are all $\mathrm{Pax} 7^{+}$progenitors within the sublaminar satellite cell compartment involved exclusively in myogenesis, and to what extent must these cells cooperate with the various other populations in order to mediate their effects in this regard? In order to help resolve such questions, a better consensus will be needed about the anatomic and phenotypic characterization of these various populations (Fig. 2). Continued application of traditional genetic lineage-tracing techniques will help to answer some of these questions of lineage and function in an in vivo setting. The advent of more sophisticated and unbiased tools for the phenotyping of individual cells, such as single-cell RNA sequencing methodologies, may become critical for resolving
Fig. 2 The name trap: function, location, or genetic identity? The muscle stem cell field, like other stem cell fields, is plagued by nomenclature bias. a Classification of skeletal muscle progenitor cells in three distinct categories, based on their nomenclature. b A Venn diagram representing established or hypothetical correlations among the different progenitor populations
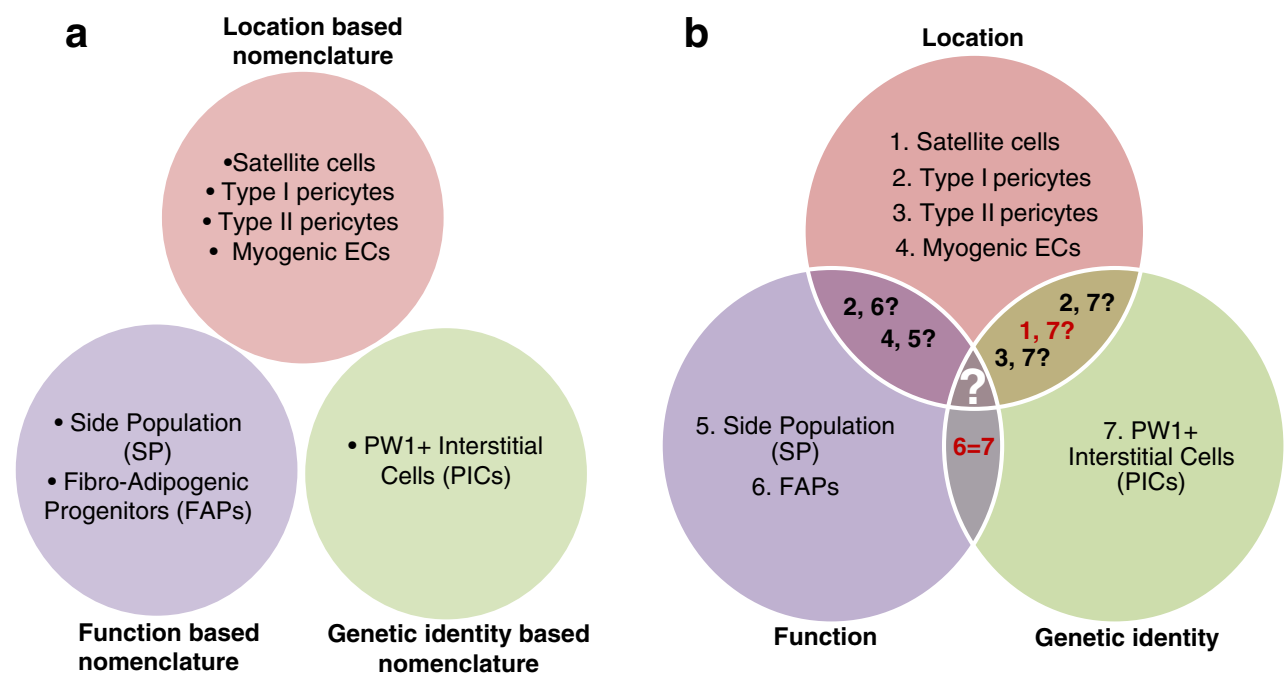
questions of identity and nomenclature that persist in this field: To what extent are type I pericytes the same as FAPs, and to what extent do these overlap with PICs? Such methodologies might also help address broad issues of stem cell biology, such as the question of whether a given muscle progenitor cell such as the satellite cell or the PIC cell represents a truly discrete entity, versus a state that exists along a continuum of several other states.

\section{Compliance with Ethical Standards}

\section{Conflict of Interest Devaveena Dey declares no conflict of interest.}

David J. Goldhamer reports grants from Alexion Pharmaceuticals, outside the submitted work.

Paul B. Yu reports grant support from the National Institutes of Health/NIAMS.

Human and Animal Rights and Informed Consent This review refers to articles by the authors in which studies on animal subjects were performed. In all cases, these studies were performed under protocols approved by the respective local institutional animal care and use committees, using practices approved by the Association for Assessment and Accreditation of Laboratory Animal Care International.

\section{References}

Papers of particular interest, published recently, have been highlighted as:

- Of importance

• Of major importance

1. Asakura A. Stem cells in adult skeletal muscle. Trends Cardiovasc Med. 2003;13(3):123-8.

2. Campbell KP, Stull JT. Skeletal muscle basement membranesarcolemma-cytoskeleton interaction minireview series. J Biol Chem. 2003;278(15):12599-600.

3. Malecova B, Puri PL. "Mix of Mics" — phenotypic and biological heterogeneity of "Multipotent" muscle interstitial cells (MICs). J Stem Cell Res Ther. 2012(Suppl 11).

4. Mauro A. Satellite cell of skeletal muscle fibers. J Biophys Biochem Cytol. 1961;9:493-5.

5. Collins CA, Olsen I, Zammit PS, Heslop L, Petrie A, Partridge TA, et al. Stem cell function, self-renewal, and behavioral heterogeneity of cells from the adult muscle satellite cell niche. Cell. 2005;122(2):289-301.

6. Montarras D, L'Honore A, Buckingham M. Lying low but ready for action: the quiescent muscle satellite cell. FEBS J. 2013;280(17):4036-50. This is a detailed review on satellite cell quiescence. The authors cover major topics on the mechanisms underlying quiescence, the protective "niche" of the quiescent satellite cell, mechanisms of crosstalk between this niche and the satellite cell, mechanisms of satellite cell activation, and heterogeneity within the quiescent satellite cell pool.

7. Seale P, Rudnicki MA. A new look at the origin, function, and "stem-cell" status of muscle satellite cells. Dev Biol. 2000;218(2): $115-24$.

8. Collins CA, Partridge TA. Self-renewal of the adult skeletal muscle satellite cell. Cell Cycle. 2005;4(10):1338-41.
9. Collins CA. Satellite cell self-renewal. Curr Opin Pharmacol. 2006;6(3):301-6.

10. Kuang S, Kuroda K, Le Grand F, Rudnicki MA. Asymmetric selfrenewal and commitment of satellite stem cells in muscle. Cell. 2007;129(5):999-1010.

11. Seale P, Sabourin LA, Girgis-Gabardo A, Mansouri A, Gruss P, Rudnicki MA. Pax7 is required for the specification of myogenic satellite cells. Cell. 2000;102(6):777-86.

12. Bosnakovski D, Xu Z, Li W, Thet S, Cleaver O, Perlingeiro RC, et al. Prospective isolation of skeletal muscle stem cells with a Pax7 reporter. Stem Cells. 2008;26(12):3194-204.

13. Fukada S, Higuchi S, Segawa M, Koda K, Yamamoto Y, Tsujikawa K, et al. Purification and cell-surface marker characterization of quiescent satellite cells from murine skeletal muscle by a novel monoclonal antibody. Exp Cell Res. 2004;296(2):245-55.

14.• Cheung TH, Quach NL, Charville GW, Liu L, Park L, Edalati A, et al. Maintenance of muscle stem-cell quiescence by microRNA489. Nature. 2012;482(7386):524-8. A seminal description of the critical role of miR-489 in maintaining satellite cell quiescence. The mechanistic basis of regulation of quiescence by microRNA-489 is described, revealing its active posttranscriptional suppression of oncogene Dek, present at high levels in differentiating daughter cells during asymmetric cell division.

15. Cerletti M, Jurga S, Witczak CA, Hirshman MF, Shadrach JL, Goodyear LJ, et al. Highly efficient, functional engraftment of skeletal muscle stem cells in dystrophic muscles. Cell. 2008;134(1):37-47.

16. Sherwood RI, Christensen JL, Conboy IM, Conboy MJ, Rando TA, Weissman IL, et al. Isolation of adult mouse myogenic progenitors: functional heterogeneity of cells within and engrafting skeletal muscle. Cell. 2004;119(4):543-54.

17. Castiglioni A, Hettmer S, Lynes MD, Rao TN, Tchessalova D, Sinha I, et al. Isolation of progenitors that exhibit myogenic/ osteogenic bipotency in vitro by fluorescence-activated cell sorting from human fetal muscle. Stem Cell Rep. 2014;2(1):92-106. The first report on isolation and characterization of human satellite cells, focusing primarily on fetal muscle. Using extensive flow cytometry-based subpopulation analysis, the authors demonstrate that $\operatorname{Pax} 7^{+}$satellite cells are highly enriched within a

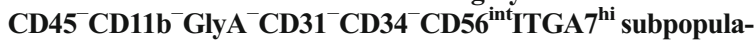
tion, which exhibit robust bipotentiality with respect to myogenic and osteogenic differentiation.

18. Wu X, Rathbone CR. Satellite cell functional alterations following cutaneous burn in rats include an increase in their osteogenic potential. J Surg Res. 2013;184(2):e9-16.

19. Burkin DJ, Wallace GQ, Milner DJ, Chaney EJ, Mulligan JA, Kaufman SJ. Transgenic expression of $\{$ alpha 7 \{beta 1 integrin maintains muscle integrity, increases regenerative capacity, promotes hypertrophy, and reduces cardiomyopathy in dystrophic mice. Am J Pathol. 2005;166(1):253-63.

20. Goldhamer DJ, Faerman A, Shani M, Emerson Jr CP. Regulatory elements that control the lineage-specific expression of myoD. Science. 1992;256(5056):538-42.

21.• Wood WM, Etemad S, Yamamoto M, Goldhamer DJ. MyoDexpressing progenitors are essential for skeletal myogenesis and satellite cell development. Dev Biol. 2013;384(1):114-27. This study dissected the hierarchial relationship between two functionally redundant myogenic regulatory factors, $\mathrm{MyoD}$ and Myf5. Using an inducible MyoD Cre model, the authors clearly demonstrate that MyoD, but not Myf5, is critical and indispensable for myogenesis during embryonic development. Another interesting observation was the concomitant decrease in Pax7 expression with MyoD ablation.

22. Kablar B, Asakura A, Krastel K, Ying C, May LL, Goldhamer DJ, et al. MyoD and Myf- 5 define the specification of musculature of 
distinct embryonic origin. Biochem Cell Biol. 1998;76(6):107991.

23. Mokalled MH, Johnson AN, Creemers EE, Olson EN. MASTR directs MyoD-dependent satellite cell differentiation during skeletal muscle regeneration. Genes Dev. 2012;26(2):190-202.

24. Relaix F, Montarras D, Zaffran S, Gayraud-Morel B, Rocancourt D, Tajbakhsh S, et al. Pax3 and Pax7 have distinct and overlapping functions in adult muscle progenitor cells. J Cell Biol. 2006;172(1):91-102. This study demonstrates the mechanistic intricacy of satellite cell differentiation at the genetic level, where "MASTR," a member of the myocardin family, was shown to upregulate MyoD during myogenic differentiation of satellite cells post muscle injury. Activation of MyoD appears to be mediated via the association of MASTR with the transcription factor, MEF2.

25.• Lepper C, Partridge TA, Fan CM. An absolute requirement for Pax7-positive satellite cells in acute injury-induced skeletal muscle regeneration. Development. 2011;138(17):3639-46. Study 25 definitively establish the role of $\operatorname{Pax} 7$ in muscle regeneration following injury.

26.• McCarthy JJ, Mula J, Miyazaki M, Erfani R, Garrison K, Farooqui $\mathrm{AB}$, et al. Effective fiber hypertrophy in satellite cell-depleted skeletal muscle. Development. 2011;138(17):3657-66. Study 26 definitively establish the role of $\operatorname{Pax} 7$ in muscle regeneration following injury. This study demonstrates that hypertrophy due to mechanical loading may be partly Pax7-independent.

27.• Sambasivan R, Yao R, Kissenpfennig A, Van Wittenberghe L, Paldi A, Gayraud-Morel B, et al. Pax7-expressing satellite cells are indispensable for adult skeletal muscle regeneration. Development. 2011;138(17):3647-56. This study definitively established the role of Pax7 in muscle regeneration following injury.

28. Segales J, Perdiguero E, Munoz-Canoves P. Epigenetic control of adult skeletal muscle stem cell functions. FEBS J. 2015;282(9): 1571-88. References $28 \& \mathbf{3 0}$ are comprehensive reviews on epigenetic and post-transcriptional regulation of satellite cells. While Ref 28 discusses the role of DNA and histone methylations in this regulation, Ref 30 discusses the role of microRNAs and long non-coding RNAs in this process.

29. Dilworth FJ, Blais A. Epigenetic regulation of satellite cell activation during muscle regeneration. Stem Cell Res Ther. 2011;2(2):18.

30. Sohi G, Dilworth FJ. Noncoding RNAs as epigenetic mediators of skeletal muscle regeneration. FEBS J. 2015;282(9):1630-46. References 28 and 30 are comprehensive reviews on epigenetic and post-transcriptional regulation of satellite cells. While ref 28 discusses the role of DNA and histone methylations in this regulation, ref 30 discusses the role of microRNAs and long non-coding RNAs in this process.

31. Gopinath SD, Webb AE, Brunet A, Rando TA. FOXO3 promotes quiescence in adult muscle stem cells during the process of selfrenewal. Stem Cell Rep. 2014;2(4):414-26.

32. McCroskery S, Thomas M, Maxwell L, Sharma M, Kambadur R. Myostatin negatively regulates satellite cell activation and selfrenewal. J Cell Biol. 2003;162(6):1135-47.

33. Mozzetta C, Consalvi S, Saccone V, Forcales SV, Puri PL, Palacios D. Selective control of Pax7 expression by TNFactivated p38alpha/polycomb repressive complex 2 (PRC2) signaling during muscle satellite cell differentiation. Cell Cycle. 2011;10(2):191-8.

34. Ogura Y, Mishra V, Hindi SM, Kuang S, Kumar A. Proinflammatory cytokine tumor necrosis factor (TNF)-like weak inducer of apoptosis (TWEAK) suppresses satellite cell selfrenewal through inversely modulating Notch and NF-kappaB signaling pathways. J Biol Chem. 2013;288(49):35159-69. References 34-36 are a series of recent reports which elegantly dissect the intricate co-regulation mediated by external factors in the satellite cell niche on satellite cell function. The first highlight is the critical role of Notch signaling in this regulatory process, reported in two independent studies (Ref 34 and 35), while the second highlight is the dynamic role of inflammatory cytokines (Ref 32) and macrophages (Ref 36) on regulation of satellite cell function. These studies have created a sub-field in satellite cell biology, on the role of immune mediated regulation of stem cell function.

35. Hindi SM, Paul PK, Dahiya S, Mishra V, Bhatnagar S, Kuang S, et al. Reciprocal interaction between TRAF6 and notch signaling regulates adult myofiber regeneration upon injury. Mol Cell Biol. 2012;32(23):4833-45. References 34-36 are a series of recent reports which elegantly dissect the intricate co-regulation mediated by external factors in the satellite cell niche on satellite cell function. The first highlight is the critical role of Notch signaling in this regulatory process, reported in two independent studies (Ref 34 and 35), while the second highlight is the dynamic role of inflammatory cytokines (Ref 32) and macrophages (Ref 36) on regulation of satellite cell function. These studies have created a sub-field in satellite cell biology, on the role of immune mediated regulation of stem cell function.

36. Zhang J, Xiao Z, Qu C, Cui W, Wang X, Du J. CD8 T cells are involved in skeletal muscle regeneration through facilitating MCP-1 secretion and Gr1(high) macrophage infiltration. J Immunol. 2014;193(10):5149-60. References 34-36 are a series of recent reports which elegantly dissect the intricate co-regulation mediated by external factors in the satellite cell niche on satellite cell function. The first highlight is the critical role of Notch signaling in this regulatory process, reported in two independent studies (refs 34 and 35), while the second highlight is the dynamic role of inflammatory cytokines (ref 32) and macrophages (ref 36) on regulation of satellite cell function. These studies have created a sub-field in satellite cell biology, on the role of immune-mediated regulation of stem cell function.

37. Hauerslev S, Vissing J, Krag TO. Muscle atrophy reversed by growth factor activation of satellite cells in a mouse muscle atrophy model. PLoS One. 2014;9(6):e100594.

38. Diaz-Ruiz A, Gonzalez-Freire M, Ferrucci L, Bernier M, de Cabo R. SIRT1 synchs satellite cell metabolism with stem cell fate. Cell Stem Cell. 2015;16(2):103-4. References 38-39 represents a recent series of reports underscoring the importance of the satellite cell 'metabolome' in its function and regulation. Ref. 39 demonstrates the importance of autophagy during transition of satellite cells from quiescence, with autophagy in part being mediated by SIRT1, while Ref 38 reports a concomitant decrease in the histone deacetylase activity of SIRT1 and in NAD+ levels during satellite cell activation, elegantly demonstrating the link between metabolic changes and epigenetic reguation during satellite cell activation.

39. Tang AH, Rando TA. Induction of autophagy supports the bioenergetic demands of quiescent muscle stem cell activation. EMBO J. 2014;33(23):2782-97. References 38-39 represents a recent series of reports underscoring the importance of the satellite cell 'metabolome' in its function and regulation. Ref. 39 demonstrates the importance of autophagy during transition of satellite cells from quiescence, with autophagy in part being mediated by SIRT1, while Ref 38 reports a concomitant decrease in the histone deacetylase activity of SIRT1 and in NAD+ levels during satellite cell activation, elegantly demonstrating the link between metabolic changes and epigenetic reguation during satellite cell activation.

40. Shan T, Zhang P, Liang X, Bi P, Yue F, Kuang S. Lkb1 is indispensable for skeletal muscle development, regeneration, and satellite cell homeostasis. Stem Cells. 2014;32(11):2893-907. Refs 40 and 41 independently establish the importance of the mTOR pathway in satellite cell quiescence. 
41. Rodgers JT, King KY, Brett JO, Cromie MJ, Charville GW, Maguire KK, et al. mTORC1 controls the adaptive transition of quiescent stem cells from G0 to G(alert). Nature. 2014;510(7505): 393-6. Ref 40 and 41 independently establish the importance of the mTOR pathway in satellite cell quiescence. While Ref 38 demonstrates that the Serine/threonine kinase Lkb1 maintains satellite cell queiscence via the mTOR pathway, and promotes myogenic differenitation via activation of Wnt pathway, Ref 41 elegantly demonstrates the requirement of the mTOR pathway in transition of satellite cells (and other stem cell populations) from the 'quiescence' (G0) phase to a 'pre-activation' (G(Alert)) phase.

42. Sinha M, Jang YC, Oh J, Khong D, Wu EY, Manohar R, et al. Restoring systemic GDF11 levels reverses age-related dysfunction in mouse skeletal muscle. Science. 2014;344(6184):649-52.

43. Brack AS, Conboy MJ, Roy S, Lee M, Kuo CJ, Keller C, et al. Increased Wnt signaling during aging alters muscle stem cell fate and increases fibrosis. Science. 2007;317(5839):807-10.

44. Sriram S, Subramanian S, Sathiakumar D, Venkatesh R, Salerno MS, McFarlane CD, et al. Modulation of reactive oxygen species in skeletal muscle by myostatin is mediated through NF-kappaB. Aging Cell. 2011;10(6):931-48.

45. Mendias CL, Bakhurin KI, Gumucio JP, Shallal-Ayzin MV, Davis CS, Faulkner JA. Haploinsufficiency of myostatin protects against aging-related declines in muscle function and enhances the longevity of mice. Aging Cell. 2015.

46.• Sousa-Victor P, Gutarra S, Garcia-Prat L, Rodriguez-Ubreva J, Ortet L, Ruiz-Bonilla V, et al. Geriatric muscle stem cells switch reversible quiescence into senescence. Nature. 2014;506(7488):316-21. This study established the mechanism underlying the failure of activation of aged "quiescent" satellite cells as an irreversible shift from quiescence to senescence, demonstrating that this shift is mediated by the derepression of the tumor suppressor, p16 (INK4a).

47.• Uezumi A, Fukada S, Yamamoto N, Takeda S, Tsuchida K. Mesenchymal progenitors distinct from satellite cells contribute to ectopic fat cell formation in skeletal muscle. Nat Cell Biol. 2010;12(2):143-52. References 47-48 were the first reports which identified and characterized the 'fibro-adipogenic progenitors' (FAPs). While Ref 47 reported the presence of 'adipogenic progenitors' within the muscle as distinct from satellite cells, Ref $\mathbf{4 8}$ described a muscle resident non-satellite cell population that facilitates injury-induced satellite cell mediated myogenic differentiation.

48.• Joe AW, Yi L, Natarajan A, Le Grand F, So L, Wang J, et al. Muscle injury activates resident fibro/adipogenic progenitors that facilitate myogenesis. Nat Cell Biol. 2010;12(2):153-63. References 47-48 were the first reports which identified and characterized the 'fibro-adipogenic progenitors' (FAPs). While Ref 47 reported the presence of 'adipogenic progenitors' within the muscle as distinct from satellite cells, Ref $48 \mathrm{de}-$ scribed a muscle resident non-satellite cell population that facilitates injury-induced satellite cell mediated myogenic differentiation.

49. Uezumi A, Ito T, Morikawa D, Shimizu N, Yoneda T, Segawa M, et al. Fibrosis and adipogenesis originate from a common mesenchymal progenitor in skeletal muscle. J Cell Sci. 2011;124(Pt 21): 3654-64. Ref 49 established that both these populations derived from a common FAP distinct from satellite cells.

50. Mozzetta C, Consalvi S, Saccone V, Tierney M, Diamantini A, Mitchell KJ, et al. Fibroadipogenic progenitors mediate the ability of HDAC inhibitors to promote regeneration in dystrophic muscles of young, but not old Mdx mice. EMBO Mol Med. 2013;5(4): 626-39.
51. Birbrair A, Zhang T, Wang ZM, Messi ML, Mintz A, Delbono O. Pericytes: multitasking cells in the regeneration of injured, diseased, and aged skeletal muscle. Front Aging Neurosci. 2014;6: 245.

52. Crisan M, Corselli M, Chen WC, Peault B. Perivascular cells for regenerative medicine. J Cell Mol Med. 2012;16(12):2851-60. This is a useful review on the location, phenotype, and function of perivascular cells, specifically pericytes and adventitial cells, and the distinction between the two populations.

53. Bergwerff M, Verberne ME, DeRuiter MC, Poelmann RE, Gittenberger-de Groot AC. Neural crest cell contribution to the developing circulatory system: implications for vascular morphology? Circ Res. 1998;82(2):221-31.

54. Birbrair A, Zhang T, Files DC, Mannava S, Smith T, Wang ZM, et al. Type-1 pericytes accumulate after tissue injury and produce collagen in an organ-dependent manner. Stem Cell Res Ther. 2014;5(6):122

55. Dellavalle A, Sampaolesi M, Tonlorenzi R, Tagliafico E, Sacchetti B, Perani L, et al. Pericytes of human skeletal muscle are myogenic precursors distinct from satellite cells. Nat Cell Biol. 2007;9(3): 255-67.

56. Birbrair A, Zhang T, Wang ZM, Messi ML, Enikolopov GN, Mintz A, et al. Role of pericytes in skeletal muscle regeneration and fat accumulation. Stem Cells Dev. 2013;22(16):2298-314.

57. Crisan M, Yap S, Casteilla L, Chen CW, Corselli M, Park TS, et al. A perivascular origin for mesenchymal stem cells in multiple human organs. Cell Stem Cell. 2008;3(3):301-13.

58. Birbrair A, Zhang T, Wang ZM, Messi ML, Enikolopov GN, Mintz A, et al. Skeletal muscle neural progenitor cells exhibit properties of NG2-glia. Exp Cell Res. 2013;319(1):45-63.

59. Sampaolesi M, Torrente $Y$, Innocenzi A, Tonlorenzi R, D'Antona G, Pellegrino MA, et al. Cell therapy of alpha-sarcoglycan null dystrophic mice through intra-arterial delivery of mesoangioblasts. Science. 2003;301(5632):487-92.

60. Galvez BG, Sampaolesi M, Brunelli S, Covarello D, Gavina M, Rossi B, et al. Complete repair of dystrophic skeletal muscle by mesoangioblasts with enhanced migration ability. J Cell Biol. 2006;174(2):231-43.

61. Dellavalle A, Maroli G, Covarello D, Azzoni E, Innocenzi A, Perani L, et al. Pericytes resident in postnatal skeletal muscle differentiate into muscle fibres and generate satellite cells. Nat Commun. 2011;2:499. An important report demonstrating a direct contribution of muscle-resident pericytes to populate the satellite cell compartment during resting state. Authors show this contribution increases during injury or during chronic myogenic turnover, as seen in muscular dystrophy patients.

62. Birbrair A, Wang ZM, Messi ML, Enikolopov GN, Delbono O. Nestin-GFP transgene reveals neural precursor cells in adult skeletal muscle. PLoS One. 2011;6(2):e16816.

63. Birbrair A, Zhang T, Wang ZM, Messi ML, Enikolopov GN, Mintz A, et al. Skeletal muscle pericyte subtypes differ in their differentiation potential. Stem Cell Res. 2013;10(1):67-84.

64. Birbrair A, Zhang T, Wang ZM, Messi ML, Mintz A, Delbono O. Type-1 pericytes participate in fibrous tissue deposition in aged skeletal muscle. Am J Physiol Cell Physiol. 2013;305(11):C1098 113. This study describes the effect of aging on the function of muscle-associated pericytes. A distinction is made between "Type 1" (fibrogenic) and "Type 2" (myogenic) pericytes, on the basis of their cell surface markers and function, followed by the demonstration that aging decreases the myogenic potential of type 2 pericytes while increasing collagen deposition by type 1 pericytes.

65. Shimizu F, Sano Y, Saito K, Abe MA, Maeda T, Haruki H, et al. Pericyte-derived glial cell line-derived neurotrophic factor 
increase the expression of claudin-5 in the blood-brain barrier and the blood-nerve barrier. Neurochem Res. 2012;37(2):401-9.

66. Shimizu F, Sano Y, Abe MA, Maeda T, Ohtsuki S, Terasaki T, et al. Peripheral nerve pericytes modify the blood-nerve barrier function and tight junctional molecules through the secretion of various soluble factors. J Cell Physiol. 2011;226(1):255-66.

67. Scheef EA, Sorenson CM, Sheibani N. Attenuation of proliferation and migration of retinal pericytes in the absence of thrombospondin-1. Am J Physiol Cell Physiol. 2009;296(4): C724-34.

68. Merfeld-Clauss S, Lupov IP, Lu H, Feng D, Compton-Craig P, March KL, et al. Adipose stromal cells differentiate along a smooth muscle lineage pathway upon endothelial cell contact via induction of activin A. Circ Res. 2014;115(9):800-9.

69. Goodell MA, Brose K, Paradis G, Conner AS, Mulligan RC. Isolation and functional properties of murine hematopoietic stem cells that are replicating in vivo. J Exp Med. 1996;183(4):1797806.

70. Gussoni E, Soneoka Y, Strickland CD, Buzney EA, Khan MK, Flint AF, et al. Dystrophin expression in the mdx mouse restored by stem cell transplantation. Nature. 1999;401(6751):390-4.

71. Asakura A, Seale P, Girgis-Gabardo A, Rudnicki MA. Myogenic specification of side population cells in skeletal muscle. J Cell Biol. 2002;159(1):123-34.

72. Majka SM, Jackson KA, Kienstra KA, Majesky MW, Goodell MA, Hirschi KK. Distinct progenitor populations in skeletal muscle are bone marrow derived and exhibit different cell fates during vascular regeneration. J Clin Invest. 2003;111(1):71-9.

73. Penton CM, Thomas-Ahner JM, Johnson EK, McAllister C, Montanaro F. Muscle side population cells from dystrophic or injured muscle adopt a fibro-adipogenic fate. PLoS One. 2013;8(1):e54553. This study demonstrates the propensity of SP cells from young muscles to undergo myogenic differentiation, while undergoing fibro-adipogenic differentiation when isolated from older muscles.

74. Belicchi M, Erratico S, Razini P, Meregalli M, Cattaneo A, Jacchetti E, et al. Ex vivo expansion of human circulating myogenic progenitors on cluster-assembled nanostructured $\mathrm{TiO} 2$. Biomaterials. 2010;31(20):5385-96.

75. Gavina M, Belicchi M, Rossi B, Ottoboni L, Colombo F, Meregalli M, et al. VCAM-1 expression on dystrophic muscle vessels has a critical role in the recruitment of human bloodderived CD133+ stem cells after intra-arterial transplantation. Blood. 2006;108(8):2857-66.

76. Tamaki T, Akatsuka A, Yoshimura S, Roy RR, Edgerton VR. New fiber formation in the interstitial spaces of rat skeletal muscle during postnatal growth. J Histochem Cytochem. 2002;50(8):1097111 .

77. Chen CW, Corselli M, Peault B, Huard J. Human blood-vesselderived stem cells for tissue repair and regeneration. J Biomed Biotechnol. 2012;2012:597439.

78. Zheng B, Cao B, Crisan M, Sun B, Li G, Logar A, et al. Prospective identification of myogenic endothelial cells in human skeletal muscle. Nat Biotechnol. 2007;25(9):1025-34.

79. Huang P, Schulz TJ, Beauvais A, Tseng YH, Gussoni E. Intramuscular adipogenesis is inhibited by myo-endothelial progenitors with functioning Bmprla signalling. Nat Commun. 2014;5:4063.

80. Relaix F, Wei X, Li W, Pan J, Lin Y, Bowtell DD, et al. Pw1/Peg3 is a potential cell death mediator and cooperates with Siah1a in p53-mediated apoptosis. Proc Natl Acad Sci U S A. 2000;97(5): 2105-10.

81. Relaix F, Wei XJ, Wu X, Sassoon DA. Peg3/Pw1 is an imprinted gene involved in the TNF-NFkappaB signal transduction pathway. Nat Genet. 1998;18(3):287-91.
82. Nicolas N, Marazzi G, Kelley K, Sassoon D. Embryonic deregulation of muscle stress signaling pathways leads to altered postnatal stem cell behavior and a failure in postnatal muscle growth. Dev Biol. 2005;281(2):171-83.

83. Mitchell KJ, Pannerec A, Cadot B, Parlakian A, Besson V, Gomes $\mathrm{ER}$, et al. Identification and characterization of a non-satellite cell muscle resident progenitor during postnatal development. Nat Cell Biol. 2010;12(3):257-66.

84.• Pannerec A, Formicola L, Besson V, Marazzi G, Sassoon DA. Defining skeletal muscle resident progenitors and their cell fate potentials. Development. 2013;140(14):2879-91. This study distinguishes between ${ }^{+}$satellite cells and $\mathrm{PW1}^{+}$interstitial cells (PICs), the former representing a primarily myogenic precursor, the latter possessing "mesenchymal stem cell"-like properties. Among the PICs, the authors demonstrate a PDGFR $\alpha+$ PIC subpopulation with high fibro-adipogenic potential, while PICs with myogenic potential are PDGFR $\alpha-$.

85. Besson V, Smeriglio P, Wegener A, Relaix F, Nait Oumesmar B, Sassoon DA, et al. PW1 gene/paternally expressed gene 3 (PW1/Peg3) identifies multiple adult stem and progenitor cell populations. Proc Natl Acad Sci U S A. 2011;108(28):11470 5. References 85-86 establish the transcription factor PW1 as a stem cell master molecule in multiple tissues. PW1+ cells isolated from different tissues, comprising all three germ layers, were highly enriched in self-renewing stem cells, which under suitable conditions could undergo multilineage differentiation.

86. Bonfanti C, Rossi G, Tedesco FS, Giannotta M, Benedetti S, Tonlorenzi R, et al. PW1/Peg3 expression regulates key properties that determine mesoangioblast stem cell competence. Nat Commun. 2015;6:6364. References 85 and 86 establish the transcription factor PW1 as a stem cell master molecule in multiple tissues. $\mathrm{PW1}^{+}$cells isolated from different tissues, comprising all three germ layers, were highly enriched in self-renewing stem cells, which under suitable conditions could undergo multilineage differentiation.

87. Kaminski HJ, al-Hakim M, Leigh RJ, Katirji MB, Ruff RL. Extraocular muscles are spared in advanced Duchenne dystrophy. Ann Neurol. 1992;32(4):586-8.

88. Formicola L, Marazzi G, Sassoon DA. The extraocular muscle stem cell niche is resistant to ageing and disease. Front Aging Neurosci. 2014;6:328. This study analyzes the changes in number, function, and balance between PICs and satellite cells in the extraocular muscles (EOM), which are highly resistant to aging and myopathies. The authors find distinct differences in the balance of PICs and satellite cells between the tibialis anterior (TA) muscles and EOM with aging.

89. Vanden Bossche L, Vanderstraeten G. Heterotopic ossification: a review. J Rehabil Med. 2005;37(3):129-36.

90. de Vlam K, Lories RJ, Luyten FP. Mechanisms of pathologic new bone formation. Curr Rheumatol Rep. 2006;8(5):332-7.

91. Lories RJ, Derese I, Luyten FP. Modulation of bone morphogenetic protein signaling inhibits the onset and progression of ankylosing enthesitis. J Clin Invest. 2005;115(6):1571-9.

92. Shore EM, Xu M, Connor JM, Kaplan FS. Mutations in the BMP type I receptor ACVR1 in patients with fibrodysplasia ossificans progressiva (FOP). J Bone Miner Res. 2006;21:S75.

93. Mavrogenis AF, Soucacos PN, Papagelopoulos PJ. Heterotopic ossification revisited. Orthopedics. 2011;34(3):177.

94. Hashimoto N, Kiyono T, Wada MR, Umeda R, Goto Y, Nonaka I, et al. Osteogenic properties of human myogenic progenitor cells. Mech Dev. 2008;125(3-4):257-69.

95. Levy MM, Joyner CJ, Virdi AS, Reed A, Triffitt JT, Simpson AH, et al. Osteoprogenitor cells of mature human skeletal muscle tissue: an in vitro study. Bone. 2001;29(4):317-22. 
96. Oishi T, Uezumi A, Kanaji A, Yamamoto N, Yamaguchi A, Yamada $\mathrm{H}$, et al. Osteogenic differentiation capacity of human skeletal muscle-derived progenitor cells. PLoS One. 2013;8(2): e56641.

97. Medici D, Shore EM, Lounev VY, Kaplan FS, Kalluri R, Olsen BR. Conversion of vascular endothelial cells into multipotent stem-like cells. Nat Med. 2010;16(12):1400-6. This study reported the conversion of endothelial cells to multipotent mesenchymal-like cells, under the influence of the BMP type I receptor, ALK2, or following treatment with BMP or TGF- $\beta$ ligands. These "endothelial-to-mesenchymal"-converted cells could differentiate into osteocyte, chondrocyte, and adipocyte lineages.

98. Wosczyna MN, Biswas AA, Cogswell CA, Goldhamer DJ. Multipotent progenitors resident in the skeletal muscle interstitium exhibit robust BMP-dependent osteogenic activity and mediate heterotopic ossification. J Bone Miner Res. 2012;27(5):1004-17.

99. Chandra S, Terragni J, Zhang G, Pradhan S, Haushka S, Johnston $\mathrm{D}$, et al. Tissue-specific epigenetics in gene neighborhoods: myogenic transcription factor genes. Hum Mol Genet. 2015.

100. Braun T, Arnold HH. Myf-5 and myoD genes are activated in distinct mesenchymal stem cells and determine different skeletal muscle cell lineages. EMBO J. 1996;15(2):310-18.

101. Marti M, Montserrat N, Pardo C, Mulero L, Miquel-Serra L, Rodrigues AM, et al. M-cadherin-mediated intercellular interactions activate satellite cell division. J Cell Sci. 2013;126(Pt 22):5116-31.

102. Armulik A, Genove G, Betsholtz C. Pericytes: developmental, physiological, and pathological perspectives, problems, and promises. Dev Cell. 2011;21(2):193-215. 